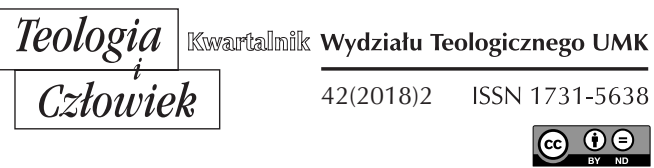

JAKUB J. WOŹNIAK*

TORUŃ

ORCID: 0000-0002-3994-619X

\title{
TRZY WIELKIE SYMBOLE CHRZCIELNE WIGILII PASCHALNEJ W NAUCZANIU JOSEPHA RATZINGERA - BENEDYKTA XVI
}

DOI: http://dx.doi.org/10.12775/TiCz.2018.018

\section{WSTĘP}

Wigilia Paschalna jest nasycona bogactwem symboli ${ }^{1}$, poprzez które Kościół pragnie wiernym ukazać prawdziwy sens, znaczenie i do-

* Jakub J. Woźniak - doktorant nauk teologicznych na Wydziale Teologicznym Uniwersytetu Mikołaja Kopernika w Toruniu; student drugiego stopnia Nauk o Rodzinie; Przewodniczący Komisji Dydaktyki i Jakości Kształcenia w Samorządzie Studenckim UMK; Wiceprzewodniczący Samorządu Studenckiego UMK; Przewodniczący Wydziałowej Rady Samorządu Studenckiego Wydziału Teologicznego UMK; Prezes Koła Naukowego Cooperatores Veritatis im. Benedykta XVI (jakub88w@gmail.com).

1 Terminu „symbol” używamy w znaczeniu szerokim, mając świadomość różnicy pomiędzy znakiem a symbolem.

„Symbol” w Leksykonie religii został ujęty w sposób następujący: „Ogólnie biorąc symbol, jeśli chodzi o formę, należy zaliczyć do znaków, ponieważ oznacza coś, a zatem nie istnieje wyłącznie dla siebie, lecz wskazuje sobą na coś innego. Ten charakter symbolu, a mianowicie odnoszenia do czegoś innego, łączy płaszczyznę przedstawienia zmysłowego i znaczenia duchowego". P. Parusel, Symbol, tłum. Z. Wesołowski, w: Leksykon religii, red. H. Waldenfels, Warszawa 1997, s. 446. Z kolei B. Nadolski termin ten przedstawia następująco: „Etymologicznie słowo symbol wywodzi się od greckiego wyrażenia synballein 
niosłość tej nocy. W tym dniu trzy symbole w sposób szczególny wpisują się w kulminacyjny dzień roku liturgicznego, który stanowi święto życia sakramentalnego każdego wierzącego. W czasie Wielkiej Nocy Kościół pragnie nasycić umysły wiernych bogactwem tego, co sprawuje, pragnie im ukazać i przypomnieć początek życia wiary, życia dziecka Bożego. Kościół w liturgii światła, liturgii chrzcielnej oraz w uroczystym „Alleluja” wprowadza wiernych $\mathrm{w}$ atmosferę festum fiedi, święta, które wszczepia w nowe życie, które otwiera na nadzieję i jest nasycone miłością. W sprawowaniu wielkiej tajemnicy tej najświętszej z nocy uobecniane jest to, do

- rzucać razem, łączyć, zbierać, tworzyć jedno, wzajemnie wymieniać, porównywać, okazywać gościnność; jako słowo nieprzechodnie = spotykać się, rozmawiać, rzeczownikowo symbole $=$ związek, wiązanie (staw, kolano, łokieć), pakt, kontrakt, symbollon to przedmiot przełamany na dwie części, który łączy się dla identyfikacji. Symbol to przedmiot, słowo, gest, osoba, które wymienione w grupie pozwalają tej grupie spotkać się, identyfikować, tworzą bezpośredniość, usuwają dystans. Symbole są przeto pośrednikami identyfikacji. Symbol nie odsyła, tak jak znak, do rzeczywistości innej, poza nim samym, lecz wprowadza w tę rzeczywistość, otwiera ją. Symbol jest częścią rzeczywistości, partycypuje w niej. [...] Symbol jest wychowawcą ku temu, co niewidzialne". B. Nadolski, Liturgia, t. 1: Liturgika fundamentalna, Poznań $2014^{2}$, s. 41. U Zygfryda Glaesera czytamy: „Językiem liturgii jest język symbolu. Symbol staje się kategorią, poprzez którą człowiek potrafi głębiej wyrazić Bożą obecność oraz wspólnotę, jaka nawiązuje się pomiędzy Stwórcą i Jego stworzeniem. Przygotowuje także na spotkanie z ukrytą i niepojętą dla ludzkiego rozumu eschatyczną rzeczywistością powtórnego przyjścia Chrystusa w mocy Ducha Świętego. Otwiera dostęp do bardziej egzystencjalnego zrozumienia sensu tajemnicy. Język symbolu niejednokrotnie lepiej wyraża rzeczywistość niż język pojęć. Nissiotis określa język symbolu jako «język Kościoła pomiędzy krzyżem, zmartwychwstaniem i paruzją»", Z. Glaeser, Liturgiczne „doświadczenie” misterium Boga według teologii prawosławnej, „Liturgia Sacra. Liturgia - Musica - Ars”, 2 (1996) 3-4, s. 51. „Symbole nie tyle wskazują na rzeczywistość ukrytą, «wskazują poza siebie», lecz są częścią oznaczonej rzeczywistości, «uczestnictwem w świecie niebiańskim». Przekraczają one naturalnie i alegorię, i znaki, a także posiadają własne bytowe znaczenie. Reprezentują inną rzeczywistość, którą antycypują, nie będąc z nią identycznymi. [...] Prawdziwy symbol tworzy jedność daru przymierza i udziału w bycie (łączy «być» z actio - działaniem). Symbol dąży do syntezy obu rzeczywistości, a więc przezwycięża dychotomię świata stworzonego i transcendentnego". B. Nadolski, Leksykon symboli liturgicznych. Per visibilia ad invisibilia, Kraków 2012, s. 22. Symbole „Oddziałując na wyobraźnię, pomagają sprowadzać całe życie do jedności i ukazują jego głębszy sens przez odniesienie do jakiejś wyższej rzeczywistości. Za widocznymi na pierwszym planie elementami rzeczy i słów takich czynności zarysowuje się głębsze tło". G. Koch, Sakramentologia - zbawienie przez sakramenty, tłum. W. Szymona, Kraków 1999 (Podręcznik teologii dogmatycznej, traktat 10, red. W. Beinert), s. 15. 
czego wierni mają się przygotować, do spotkania ze Zmartwychwstałym Barankiem nowej Paschy.

Tajemnica Wielkanocy „mówi o czymś niewyobrażalnym”, o czymś, co w ludzkim rozumieniu wykracza poza sferę poznania. Stąd jest wielką tajemnicą misterium Okupienia. Stąd w Kościele starożytnym sakramenty odnoszą się do rozumienia świata poprzez symbole, które nie są w sprzeczności z ziemską rzeczywistością, lecz ukazują nam treści, które nie są dostępne dla poznania czysto doświadczalnego, poznania empirycznego czy analizy chemicznej. Mimo że nie da się ich rozłożyć na części pierwsze, tak jak w analizie chemicznej, to jednak nie przestają one być realne. Kierują one nasze spojrzenie na wymiar wieczny, który jest dostrzegalny i obecny w świecie materialnym, stworzonym, obecnym tu i teraz, obecnym w doczesnej egzystencji człowieka ${ }^{3}$. Dlatego to „Jezus podaje nam dłoń $\mathrm{w}$ swoim wielkanocnym orędziu, w tajemnicy sakramentów, ażeby teraz dokonała się Wielkanoc, ażeby w tym świecie istniało światło nieba i żeby drzwi pozostały otwarte. Uchwyćmy Jego dłoń!”4, pisał Joseph Ratzinger. Toteż w Wielką Sobotę, w dniu, w którym Kościół wypełnia cisza i milczenie, ukazywane są wiernym trzy wielkie symbole chrzcielne, które od wydarzeń Kalwarii są znakami Zmartwychwstałego Chrystusa, rozdzierającego dzień milczenia i ukazującego wielką radość tym, którzy są tego świadkami. Tymi trzema symbolami są: światło, woda i uroczyste „Alleluja”. Stąd należy stwierdzić za Benedyktem XVI, że Pascha chrześcijańska jest świętem będącym „źródłem wszystkich świąt”. Jest świętą nocą zmartwychwstania, którą „zdominowały trzy wielkie symbole: światło, woda i «nowa pieśn» - Alleluja”, które „wiara Kościoła przełożyła wielkanocne słowa na symbole, które pozwalają przeczuć to, czego nie da

2 J. Ratzinger, Tajemnica Jezusa Chrystusa, tłum. J. Płoska, Kielce 2005², s. 111.

${ }^{3}$ Por. tenże, Teologia liturgii. Sakramentalne podstawy życia chrześcijańskiego (Opera Omnia, t. 11), red. pol. K. Góźdź, M. Górecka, tłum. W. Szymona, Lublin 2012, s. 194.

${ }^{4}$ Tenże, Tajemnica Jezusa Chrystusa, s. 126.

5 Benedykt XVI, W przededniu «Triduum» paschalnego, „L'Osservatore Romano”, wyd. pol., 303 (2008) 5, s. 4.

${ }^{6}$ J. Ratzinger, Jezus $z$ Nazaretu. Studia o chrystologii (Opera Omnia, t. 6/2), red. pol. K. Góźdź i M. Górecka, tłum. W. Szymona, Lublin 2015, s. 776. 
się wypowiedzieć słowem”. Należy jeszcze w tym miejscu przywołać inne słowa Benedykta XVI: „Ale co to jest zmartwychwstanie? Nie należy do naszego doświadczenia i dlatego jego przesłanie często pozostaje w jakimś stopniu niepojęte, traktowane jako coś, co należy do przeszłości. Kościół stara się doprowadzić nas do jego rozumienia, tłumacząc to tajemnicze, poruszające wydarzenie językiem symboli, w których możemy w jakiś sposób je kontemplować. W Wigilię Paschalną wskazuje nam znaczenie tego dnia przede wszystkim za pomocą trzech symboli: światła, wody i nowej pieśni - Alleluja".

\section{1.ŚWIATŁO, OGIEŃ}

W ciągu roku liturgicznego Kościół obchodzi dwie wyjątkowe noce w historii zbawienia: noc Bożego Narodzenia i noc „nowej” Paschy. W tych dwóch świętach Kościół pragnie ukazać wiernym, w kontekście symbolicznym, treść każdej z uroczystości, czyli wkroczenie w historię ludzkości niemającego początku i końca Słowa, gdzie świat nie chce dać mu miejsca i jednocześnie nie może Mu go odmówić ${ }^{9}$. „Ten Chrystusowy dramat spotykających się ze sobą światła i ciemności, Boga i świata w Boże Narodzenie zaczyna się od pukania Boga do drzwi świata, który Go nie przyjmuje, mimo iż jest Jego własnością (J 1,5.11)"10. Z kolei w dniu święta Paschy dramat ten powtarza się ${ }^{11}$ i staje się wystąpieniem przeciwko Synowi Najwyższego. Jednak w tym drugim tragicznym wydarzeniu „zmartwychwstanie przynosi wielką zmianę. Światło zwyciężyło i żyje teraz jako niepokonywane i najważniejsze. Przyciągnęło do siebie jakąś cząstkę świata i przemieniło ją w sobie"12.

7 Tenże, Tajemnica Jezusa Chrystusa, s. 111.

${ }^{8}$ Benedykt XVI, Światło zmartwychwstałego Chrystusa przenika w noce dziejów, „L'Osservatore Romano”, wyd. pol., 314 (2009) 6, s. 25.

9 Por. J. Ratzinger, Jezus z Nazaretu. Studia o chrystologii (Opera Omnia, t. 6/2), s. 776.

10 J. Ratzinger, Jezus z Nazaretu. Studia o chrystologii, s. 776.

11 Por. J. Ratzinger, Jezus z Nazaretu. Studia o chrystologii, s. 777.

12 J. Ratzinger, Jezus z Nazaretu. Studia o chrystologii, s. 777. 
W dzień poranku wielkanocnego „pierwszego dnia tygodnia, Bóg na nowo powiedział: «Niechaj się stanie światłość!». Poprzedziła to noc Góry Oliwnej, zaćmienie słońca w czasie męki i śmierci Jezusa, noc grobu. Ale teraz znów jest pierwszy dzień - zaczyna się całkiem nowe stworzenie. «Niechaj się stanie światłość!» - powiedział Bóg - i «stała się światłość». Jezus wstaje z grobu. Życie jest silniejsze niż śmierć. Dobro jest silniejsze niż zło. Miłość jest silniejsza od nienawiści. Prawda jest silniejsza od kłamstwa. Ciemność minionych dni zostaje rozproszona w chwili, gdy Jezus wstaje $z$ grobu i sam staje się czystym światłem Boga"13. Ten Chrystusowy tryumf nad ciemnością jest, jak określa to Benedykt XVI, „erupcją światłości” ${ }^{14}$, światłości, która wkracza w noc dziejów, w noc, która zostaje zastąpiona dniem, nowym dniem ${ }^{15}$.

W kontekście powyższych słów należy wrócić do samych początków świata: do dzieła stworzenia. Nim jednak do tego nawiążemy, należy stwierdzić za Josephem Ratzingerem, że światło „Jest to jeden z prastarych symboli ludzkości [które] stało się [...] dla ludzi obrazem tajemniczej mocy Boga podtrzymującej ich życie" ${ }^{16}$. W tym odniesieniu do świata ludów pierwotnych, do wielkich religii świata, Benedykt XVI w czasie Wigilii Paschalnej zauważa: „Opis stworzenia zaczyna się symbolicznie od stworzenia światła. Słońce i księżyc zostają stworzone dopiero w czwartym dniu. W opisie stworzenia są nazwane ciałami jaśniejącymi, które Bóg umieścił na sklepieniu nieba. Tym samym świadomie zostają pozbawione charakteru boskiego, jaki przypisywały im wielkie religie" ${ }^{17}$. Należy po-

13 Benedykt XVI, Wielkanoc to dzień nowego stworzenia, „L'Osservatore Romano” wyd. pol. 343 (2012) 5, s. 20.

14 Tenże, Światło zmartwychwstałego Chrystusa przenika w noce dziejów, s. 25.

15 Por. Tenże, Światło zmartwychwstałego Chrystusa przenika $w$ noce dziejów, s. 25 .

${ }^{16}$ J. Ratzinger, Jezus z Nazaretu. Studia o chrystologii (Opera Omnia, t. 6/2), s. 776 .

17 Benedykt XVI, Wielkanoc to dzień nowego stworzenia, „L'Osservatore Romano” wyd. pol. 343 (2012) 5, s. 20. W „Studium generale” w 1960 roku ukazał się artykuł Światło i oświecenie. Rozważania o miejscu i rozwoju tego zagadnienia $w$ duchowych dziejach Zachodu", w którym Joseph Ratzinger ukazuje związek życia i światła. W odniesieniu do słów z Księgi Rodzaju: „Niech się stanie światłość” (Rdz 1,3) napisał tak: „Trafnie wskazuje to na rangę światła w życiu człowieka i ludzkości w ogóle. Człowiek wie, że życie i światło wzajemnie od siebie zależą, że jego życie zależy od światła i że go wymaga. Poza 
wiedzieć, że tam, gdzie dominuje światło, gdzie ono jest, powstaje i może istnieć życie, chaos porządkuje się i zamienia się w kosmos. W przesłaniu Biblii światłość jest obrazem wskazującym na Boga, który jest Jasnością, Światłością, Życiem i Prawdą ${ }^{18}$. W tym kontekście widoczne staje się to, że światło jest spotkaniem, komunikacją, poznaniem, dostępem do rzeczywistości i do prawdy. Światło umożliwia poznanie, wolność i postęp. I przede wszystkim światło umożliwia nam możliwość działania ${ }^{19}$.

Jeśli chodzi o kontekst starotestamentalny, to pozostaje jeszcze jedna kwestia światłości, mianowicie chodzi o Torę, która jest uważana za światłość pochodzącą z Boskiej mądrości. Tak samo i chrześcijanie widzieli, że w Chrystusie jest ona obecna. To Słowo Boże jest pochodzącą od Boga Światłością (por. Ps 19) ${ }^{20}$.

W związku ze światłem, w ścisłej łączności istnieje ogień. Jego symbolika wyraża związek człowieka z Bogiem. Ten związek wyraża się w doświadczeniu wewnętrznym, w „gorącu”, w żarze, gdzie Bóg objawia się w swojej energii, gdzie ogień staje się obrazem obecności Najwyższego $^{21}$. W tym odniesieniu zauważyć można, że „Ogień jest siłą, która kształtuje świat, mocą, która przemienia. Ogień - dodaje Benedykt XVI daje też ciepło. Także w tym znów jest widoczne misterium Chrystusa. Chrystus, światło, jest ogniem, jest płomieniem, który spala zło, przemieniając w ten sposób świat i nas samych. «Kto jest blisko Mnie, jest blisko ognia», brzmią słowa Jezusa przekazane nam przez Orygenesa. Ten ogień jest zarazem ciepłem, nie zimnym światłem, ale światłem, które daje nam odczucie ciepła i dobroci Boga"22.

konkretnymi źródłami światła jest ono dla niego zjawiskiem pierwotnym, w którym zdaje się dotykać tajemniczego źródła rzeczy, mocy, która poprzedza jego życie i je podtrzymuje. Dlatego jest zrozumiałe, że światło stało się jedną z podstawowych religijnych kategorii ludzkości, która w pewnej formie jest wyraźnie obecna w każdej religii”. J. Ratzinger, Rozumienie objawienia $i$ teologii historii według Bonawentury. Rozprawa habilitacyjna i studia nad Bonawentura (Opera Omnia, t. 2), red. pol. K. Góźdź i M. Górecka, tłum. J. Merecki, Lublin 2014, s. 636.

${ }_{18}$ Por. Benedykt XVI, Światło zmartwychwstałego Chrystusa przenika w noce dziejów, s. 25.

19 Por. tenże, Wielkanoc to dzień nowego stworzenia, s. 20.

${ }^{20}$ Por. tenże, Światło zmartwychwstałego Chrystusa przenika w noce dziejów, s. 25.

${ }^{21}$ Por. B. Nadolski, Liturgia, t. 1, s. 248.

${ }^{22}$ Benedykt XVI, Wielkanoc to dzień nowego stworzenia, s. 21. 
Jezus Chrystus ukazany jako światło i ogień rozprasza ciemność ludzkiego serca i ducha, wnosząc w nie światło. Dlatego to w dzień Wigilii Paschalnej Kościół wraz ze swoim ludem trwa i medytuje nad tajemnicą zapisaną w Starym i Nowym Przymierzu: nad wyzwoleniem z niewoli grzechu i śmierci ${ }^{23}$. Ogień „Obwieszcza obecność Chrystusa Światłości. Światło świec pełni rolę sygnału. Wskazuje także na fakt sprawowania liturgii, w której jest obecny Pan”24. To właśnie „Chrystus jest wielką Światłością, od której pochodzi wszelkie życie. On pozwala nam rozpoznać chwałę Bożą, rozciągającą się aż po krańce ziemi. On wskazuje nam drogę. On jest Bożym dniem, który rozprzestrzeniając się, obejmuje cały świat. Teraz, żyjąc z Nim i dla Niego, możemy żyć w światłości”25. I tak można stwierdzić, że przy chrzcie, jako sakramencie oświecenia, występuje światło, które należy rozumieć jako to, które rozprasza niewiedzę ${ }^{26}$, rozprasza ciemności świata, wprowadzając w nie prawdę. Joseph Ratzinger zauważa: „Świat jest ciemny, to prawda. Ale już jedna świeca wystarczy, ażeby rozjaśnić najgłębsze ciemności. [...] Zamiast narzekać na noc, powinniśmy się odważyć zapalić światełko dane nam przez Boga: Lumen Christi - Deo gratias"27.

W tym świetle otrzymanym od Boga w czasie chrztu należy upatrywać wiarę, która będąc światłem i lampą naszego życia, powinna przyczyniać się do tego, że świat, który przepełniony jest ciemnością ${ }^{28}$, ustępuje jasności, ustępuje porankowi wiary, dając tym samym dostęp do prawdy i wskazując do niej drogę. I tak, kiedy w tę noc ludzkości rozbłyskającą owym światełkiem powróci Pan, „nastanie niekończący się

${ }^{23}$ Por. tenże, W przededniu «Triduum» paschalnego, s. 5.

${ }^{24}$ B. Nadolski, Liturgia, t. 1, s. 248.

${ }^{25}$ Benedykt XVI, Światło zmartwychwstałego Chrystusa przenika w noce dziejów, s. 25 .

${ }^{26}$ J. Ratzinger, Lud i Dom Boży w nauce św. Augustyna o Kościele. Rozprawa doktorska oraz inne opracowania nauki Augustyna i teologii ojców Kościoła (Opera Omnia, t. 1), red. pol. K. Góźdź i M. Górecka, tłum. W. Szymona, Lublin 2014, s. 126.

27 Tenże, Jezus z Nazaretu. Studia o chrystologii (Opera Omnia, t. 6/2), s. 778.

${ }^{28}$ Kardynał Ratzinger uważa, że obecny świat jest „ciemniejszy niż kiedykolwiek”. Ciemniejszy pomimo stale rozwijającej się technologii, pomimo ciągle nowych zdobyczy nauki i osiągnięć społecznych, które to starają się za wszelką cenę poznać początki istnienia, początki tzw. pramaterii. J. Ratzinger, Jezus z Nazaretu. Studia o chrystologii (Opera Omnia, t. 6/2), s. 777. 
dzień” ${ }^{29}$. Jednak początkiem tego światła jest krzyż, z którego „rodzi się światłość”, nastaje „nowe” oświecenie. Stąd należy powrócić do antycznego określenia chrztu - fotismos, czyli do określania chrztu jako sakramentu, który oświeca, który ochrzczonego wszczepia „W światłość Chrystusa”30, który nadaje mu kierunek kroczenia przez ciemność, który rozprasza ciemną ścieżkę życia wprowadzając w nie życie i to życie zmierzające ku pełni $^{31}$. Stąd w pierwotnym Kościele osoba, która przyjmowała chrzest, stawała przodem w kierunku wschodnim, który jest symbolem światła, skąd wschodzi „nowe” słońce symbolizujące Chrystusa ${ }^{32}$.

Kolejnym symbolem Chrystusa zmartwychwstałego, w odniesieniu do symboliki światła i ognia, jest paschał, który pochodzi od łacińskiego słowa cera, czyli wosk. Stąd łacińska nazwa świecy paschalnej cereus. Ten produkt pszczelej pracy ukazuje współpracę wiernych w Kościele, współpracę całego dzieła stworzenia. Stąd stworzenie ukazać można jako to, które niesie owe światło, niesie je, aby światło zmartwychwstałego Pana dalej oświecało świat. To oświecanie świata jest możliwe dzięki ofierze spalanej świecy, która je daje. Stąd należy przyrównać spalanie się paschału do misterium Jezusa Chrystusa. To On ofiarowuje siebie i tym samym daje światło ${ }^{33}$, wprowadza je na ziemię, aby świat trwał w jasności i kroczył w świetle. Dlatego można porównać liturgię Wielkiej Soboty do drogi, którą kroczył Izrael przez pustynię, i do drogi katechumenalnej, w której to naród żydowski, jak i ci, którzy pragną przyjąć sakrament oświecenia, oraz ludzkość poszukują w każdym czasie historii człowieka światła, raju, życia, pojednania i pokoju w obłoku Zmartwychwstałego, który jest ukazany w symbolu zapalonej świecy paschalnej ${ }^{34}$. Stąd dalej można powiedzieć za Josephem Ratzingerem, że „Symbol światła (a wraz z nim i ognia) odgrywa szczególną rolę. [...] Tak oto wydarzenie z prze-

29 Tenże, Jezus z Nazaretu. Studia o chrystologii (Opera Omnia, t. 6/2), s. 777.

${ }^{30}$ Por. Benedykt XVI, Światło zmartwychwstałego Chrystusa przenika $w$ noce dziejów, s. 25.

${ }^{31}$ Por. B. Nadolski, Liturgia, t. 1, s. 247.

32 Por. Benedykt XVI, Śmierć i zmartwychwstanie Chrystusa stały się dla nas lekarstwem na wieczność, „L'Osservatore Romano” wyd. pol., 323 (2010) 6, s. 32.

${ }_{33}$ Por. tenże, Wielkanoc to dzień nowego stworzenia, s. 21.

${ }^{34}$ Por. J. Ratzinger, Wstańmy i idźmy za Chrystusem, świattem i życiem, „L'Osservatore Romano" wyd. pol., 274 (2005) 6, s. 59. 
szłości zostaje przetłumaczone na język naszych czasów: gdzie światło zwycięża ciemność, tam dokonuje się coś ze zmartwychwstania" ${ }^{35}$. Ostatecznie można powiedzieć, że światło paschału jest dla nas drogowskazem ukazującym drogę oraz pomaga nam w rozpoznaniu drugiego człowieka i nas samych ${ }^{36}$. Jest także „ciepłem, które daje siłę i wprowadza w ruch. [...] Jest wreszcie życiem, a ten drgający płomyk jest jak obraz owej cudownej tajemnicy nazwanej «życiem», która rzeczywiście jest głęboko zależna od światła" ${ }^{37}$.

Ostatnim symbolem Chrystusa związanym ze światłem jest świe$\mathrm{ca}^{38}$ chrzcielna wręczana podczas chrztu nowo ochrzczonemu członkowi wspólnoty Kościoła. Jest to

bardzo wymowny znak, który wyraża właśnie przekonanie wiary: każdy z ochrzczonych otrzymuje świecę zapaloną od paschału - jest to światło zmartwychwstałego Chrystusa, które wy zobowiązujecie się przekazać własnym dzieciom. W ten sposób z pokolenia na pokolenie my chrześcijanie przekazujemy sobie światło Chrystusa, aby On, kiedy powróci, zastał nas z tą zapaloną świecą $\mathrm{w}$ dłoniach. Podczas obrzędu powiem do was: „Podtrzymywanie tego światła powierza się wam, rodzice i chrzestni”. Podtrzymujcie zawsze, drodzy bracia i siostry, płomień wiary poprzez słuchanie i medytowanie słowa Bożego i stałą komunię z Jezusem Eucharystycznym ${ }^{39}$.

35 Tenże, Tajemnica Jezusa Chrystusa, tłum. J. Płoska, Kielce 2005², s. 111-112. Por. Benedykt XVI, Zmartwychwstanie Jezusa zakończeniem dzieła stworzenia i początkiem nowego życia, „L'Osservatore Romano” wyd. pol., 334 (2011) 6, s. 41.

${ }^{36}$ Por. tenże, Jezus z Nazaretu. Studia o chrystologii (Opera Omnia, t. 6/2), s. 778.

37 Tenże, Jezus z Nazaretu. Studia o chrystologii (Opera Omnia, t. 6/2), s. 778.

${ }^{38}$ B. Nadolski podaje, że „Świeca to symbol światła, symbol stosunku pomiędzy duchem a materią. [...] Płomień świecy oznaczał sprawy ducha, wosk - to, co zniszczeje, co przemija (Ps 68,3). Nic też nie mogło lepiej wyrazić dwóch natur w Jezusie Chrystusie jak właśnie świeca”. B. Nadolski, Leksykon symboli liturgicznych. Per visibilia ad invisibilia, Kraków 2012, s. 311.

39 Benedykt XVI, Bóg zstąpił w otchłań grzechu, aby każdemu podać rękę, „L'Osservatore Romano” wyd. pol., 300 (2008) 2, s. 36. Por. Benedykt XVI, Chrzest oświeca światłem Chrystusa i wprowadza w tajemnicę "Boga-z-nami”, „L'Osservatore Romano” wyd. pol., 320 (2010) 2, s. 22. 
Te zapalone świece, które każdy ochrzczony otrzymuje podczas chrztu, symbolizują przepowiednię „wielkiego eschatologicznego święta światła i antycypację weselnego stołu Pana, od którego bije blask niezliczonych światel”" abyśmy byli tymi, którzy są „ludźmi dnia, źródłami światła dla naszych czasów”41, abyśmy wiedzieli „kim jesteśmy, skąd przychodzimy i dokąd mamy zmierzać” ${ }^{2}$. „I tak sam Bóg ubiera nas w szaty światła, w szaty życia"43, abyśmy byli, jak Jezus, qui lucem tenebris mutavit amoris ${ }^{44}$.

\section{WODA}

Kolejnym znakiem dominującym podczas Wigilii Paschalnej jest woda, która jest nie „tylko $\mathrm{H}_{2} \mathrm{O}$, związkiem chemicznym, który w odpowiedni sposób można zmienić na inne związki i używać w najróżniejszych potrzebach”45. To właśnie ona ,jest elementem kultu we wszystkich religiach (kosmogonia). To narzędzie ożywiania, odmładzania, oczyszczania, uzdrawiania nie tylko w rzeczywistości ziemskiej, ale także po śmierci”46. Jest ona określana mianem prima materia i jako taka „bezkształtna masa symbolizuje pełnię wszelkich możliwości, prapoczątek wszelkiej egzystencji”"47.

Woda podobnie jak światło jest także prastarym symbolem, występującym w kultowości. Badacze religii mówią, że światło jest symbolem

${ }^{40}$ J. Ratzinger, Jezus z Nazaretu. Studia o chrystologii (Opera Omnia, t. 6/2), s. 778.

${ }^{41}$ Benedykt XVI, Światło zmartwychwstałego Chrystusa przenika w noce dziejów, s. 26 .

${ }^{42}$ Benedykt XVI, Nasze wielkie „tak” dla kultury życia, „L'Osservatore Romano” wyd. pol., 282 (2006) 4, s. 32.

${ }^{43}$ Benedykt XVI, Śmierć i zmartwychwstanie Chrystusa stały się dla nas lekarstwem na wieczność, s. 33.

${ }^{44}$ B. Nadolski, Leksykon symboli liturgicznych. Per visibilia ad invisibilia, s. 316.

${ }^{45}$ J. Ratzinger, Teologia liturgii. Sakramentalne podstawy życia chrześcijańskiego (Opera Omnia, t. 11), s. 194.

${ }^{46}$ B. Nadolski, Liturgia, t. 1, s. 249.

47 Tenże, Leksykon symboli liturgicznych. Per visibilia ad invisibilia, s. 375. 
rzeczywistości „niebieskiej”, a z kolei woda wyraża jej „ziemski” aspekt ${ }^{48}$. Kardynał Ratzinger te dwa symbole, światło i wodę, ujmuje następująco: „światło jest wcieleniem niezmierzonej chwały niebios, wielkiej, ale i niebezpiecznej mocy życia, która jest nad nami i którą nigdy nie rozpoznamy, gdyż ona wedle swego upodobania udziela się nam albo nie [...] woda łatwo kojarzy się z rajem i płodnością"49. Stąd wykorzystanie tych dwóch znaków podczas nocy paschalnej. Potrójne zanurzenie świecy wielkanocnej w wodzie jest symbolicznym gestem ukazującym zaślubienie tego, co niebieskie z tym, co ziemskie. Można powiedzieć dalej za Ratzingerem, że następuje „przebóstwienie ziemi”. To, co ziemskie, zostaje przeniknięte tym, co niebieskie ${ }^{50}$.

Kiedy myślimy o wodzie w Biblii, na pierwszym miejscu przychodzi nam skojarzenie z wodami Morza Czerwonego, którego wody są żywiołem wrogim dla człowieka. Symbolizują one śmierć, otchłań, w której giną Egipcjanie podążający za Izraelitami. Jednak z drugiej strony, kiedy spojrzymy na wodę w perspektywie nowotestamentalnej, ukazuje nam się jako element, który służy życiu ${ }^{51}$, sprzyja jego rozwojowi, przynosi orzeźwienie, obmywa, jest niczym matka dbająca o swoje dziecko ${ }^{52}$. Woda w Nowym Testamencie jest źródłem ${ }^{53}$, które wytrysnęło z przebitego serca Jezusa (por. J 19,34). Jest to „nowa” woda, która wzięła swój początek ze Skały Życia. Jest to „nowe” źródło, które nawadnia świat i sprawia, że staje się on miejscem, w którym życie może rozwijać się i wzrastać. To właśnie On - powiada Benedykt XVI - „jest źródłem wody żywej. Od Niego bierze początek wielka rzeka, która przez chrzest przynosi owoce i od-

${ }^{48}$ Por. J. Ratzinger, Jezus z Nazaretu. Studia o chrystologii (Opera Omnia, t. $6 / 2)$, s. 778 .

49 Tenże, Jezus z Nazaretu. Studia o chrystologii (Opera Omnia, t. 6/2), s. 778-779.

${ }^{50}$ Por. Tenże, Jezus $z$ Nazaretu. Studia o chrystologii (Opera Omnia, t. 6/2), s. $779-780$.

${ }^{51}$ Por. Benedykt XVI, Zmartwychwstanie Jezusa zakończeniem dzieła stworzenia i początkiem nowego życia, s. 41; Benedykt XVI, Światło zmartwychwstałego Chrystusa przenika $w$ noce dziejów, s. 26.

${ }^{52}$ Por. B. Nadolski, Leksykon symboli liturgicznych. Per visibilia ad invisibilia, s. 375 .

53 „Dawny Kościół widział w tym symbol chrztu i Eucharystii, biorących początek z przebitego serca Jezusa. Poprzez swoją śmierć Jezus sam stał się źródłem”. Benedykt XVI, Światło zmartwychwstałego Chrystusa przenika w noce dziejów, s. 26. 
nawia świat; wielka rzeka wody żywej - Jego Ewangelia - która użyźnia ziemię" 54 .

Wydarzenie Krzyża niesie dla ludzkości przesłanie, że właśnie tam, w tamtym miejscu,

wytrysnęło cenne źródło całkowitego oddania się, hojnie rozdającej się miłości Bożej. Zawarta jest w nim cała bezcenna wartość wody: moc oczyszczania, owocność i orzeźwiająca, pocieszająca, ożywiająca skuteczność. W chrzcie to źródło płynie z krzyża Chrystusowego jak potężna rzeka przez cały Kościół i «rozwesela miasto Boże» (Ps 45,5). W tej rzece obmywamy się i zostajemy odrodzeni. Ona jedna przemienia pustkowie świata ciągle na nowo w żyzną krainę; gdzie bowiem panuje nienawiść i egoizm, tam jest pustynia; coś nowego powstaje naprawdę tylko tam, gdzie skutecznie działa duch miłości i służy ${ }^{55}$.

Z krzyża, tak jak podkreśla Joseph Ratzinger, bije i bierze początek źródło wody, która ma moc przemieniać świat, ma moc przemieniać stworzenie i ma moc przemieniać człowieka. Nie bez powodu chrzest oznacza „zanurzenie”. To właśnie podczas chrztu w tym źródle człowiek dostępuje zanurzenia, „zgadza się na zatopienie go przez wodę śmierci, ażeby w ten sposób wejść w rzeczywistość nowego początku” ${ }^{56}$, „niejako umierając w wodzie i odradzając się do nowego życia" ${ }^{\text {"7 }}$. To wejście w rzeczywistość nowego początku, nowego życia jest przemienione dzięki miłości Chrystusa, dzięki tajemnicy krzyża. W tym źródle miłości człowiek dostępuje obmycia, oczyszczenia i przyozdobienia duszy. To prawdziwe źródło życia jest jednocześnie i śmiercią, i zmartwychwstaniem - radykalną przemianą $\dot{z ̇ y c i a}^{58}$. Stąd upatrywanie podwójnego charakteru wody: niszczenia i życia,

${ }^{54}$ Tenże, Światło zmartwychwstałego Chrystusa przenika $w$ noce dziejów, s. 26. Por. B. Nadolski, Leksykon symboli liturgicznych. Per visibilia ad invisibilia, s. 376.

${ }^{55}$ J. Ratzinger, Jezus z Nazaretu. Studia o chrystologii (Opera Omnia, t. 6/2), s. 779 .

56 Tenże, Teologia liturgii. Sakramentalne podstawy życia chrześcijańskiego (Opera Omnia, t. 11), s. 193.

${ }_{57}$ Benedykt XVI, Wasze dzieci sa cennym darem Pana, który napetnia ich serca swoją miłościa, „L’Osservatore Romano” wyd. pol., 331 (2011) 3, s. 16.

${ }^{58}$ Por. tenże, Zmartwychwstały Chrystus ogarnia cały świat, „L'Osservatore Romano" wyd. pol., 283 (2006) 5, s. 26. 
destrukcji grzechu i niesienia egzystencji ${ }^{59}$. Dlatego chrzest określany jest „powtórnym narodzeniem, ponieważ woda jest elementem życia, twórczym elementem"60.

Chrzest nazywany także bywa przez Benedykta XVI „nowym narodzeniem”61, odrodzeniem ${ }^{62}$, źródłem życia ${ }^{63}$. Określenia chrztu, przed chwilą przywołane, stają się dla papieża tym bliższe, o ile dobrze zrozumiemy to, co sam pisał po wielu latach w autobiografii:

byłem pierwszym chrześniakiem $\mathrm{z}$ nowej wody [...]. W ten sposób moje życie od początku było zagłębione w tajemnicę Świąt Wielkanocnych, co wypełniało mnie ciągle wdzięcznością, bo mogło być tylko znakiem błogosławieństwa. [...] Czym dłużej się nad tym zastanawiam, tym częściej wydaje mi się, iż zgodne jest to $\mathrm{z}$ istotą naszego ludzkiego życia, które - jeszcze nie w pełni ukształtowane, ale już pełne ufności czeka na Święto Wielkiej Nocy ${ }^{64}$.

Joseph Ratzinger rozumie wielkie znaczenie tego sakramentu w swoim życiu, stara się żyć tą wiarą, która została mu dana, stara się żyć tajemnicą Wielkanocy, tajemnicą chrztu w oczekiwaniu na Święto Wielkiej Nocy. W tej perspektywie, o której do tej pory była mowa, czytelne stają się słowa z katechezy mistagogicznej św. Cyryla Jerozolimskiego, który o wodzie pisał tak: „woda zbawienna stała się dla was równocześnie i grobem, i rodzicielką"65. Dlatego w wierze chrześcijańskiej, w tajemnicy musimy pamiętać, że „rzeczy są czymś więcej niż tylko rzeczami. Nie po-

${ }_{59}$ Por. B. Nadolski, Leksykon symboli liturgicznych. Per visibilia ad invisibilia, s. 376 .

${ }^{60}$ J. Ratzinger, Kościót - znak wśród narodów. Pisma eklezjologiczne i ekumeniczne (Opera Omnia, t. 8/2), red. pol. K. Góźdź i M. Górecka, tłum. W. Szymona, Lublin 2013, s. 1235. Por. Benedykt XVI, Nasze wielkie "tak” dla kultury życia, s. 32.

${ }^{61}$ Benedykt XVI, Piękno chrztu świętego, „L'Osservatore Romano” wyd. pol., 282 (2006) 4, s. 46.

${ }^{62}$ Por. tenże, Bóg zstąpił w otchłań grzechu, aby każdemu podać rękę, s. 35.

${ }_{63}$ Por. tenże, Niebo otwarte nad dziećmi, „L'Osservatore Romano” wyd. pol., 350 (2013) 2, s. 24.

${ }^{64}$ J. Ratzinger - Benedykt XVI, Moje życie. Autobiografia, wyd. poszerzone, tłum. W. Wiśniowski i K. Łapiński, Częstochowa $2013^{3}$, s. 8-9.

${ }^{65}$ Cyt. za: B. Nadolski, Leksykon symboli liturgicznych. Per visibilia ad invisibilia, s. 376 . 
znamy ich w pełni, gdy poznaliśmy ich właściwości fizyczne i chemiczne, bo wtedy może umknąć czyjejś uwadze cały jeden wymiar ich rzeczywistości - wskazywanie na stwórczą moc Boga, która jest ich źródłem i do której chcą prowadzić" ${ }^{66}$.

Na rzeczy, jak wskazuje Joseph Ratzinger, należy patrzeć także przez pryzmat stwórczego aktu Boga, który w każdym elemencie stworzonego świata materialnego zapisał kod, który wskazuje na Tego, który tego dzieła dokonał. To głębsze spojrzenie na akt stwórczy ma przypominać, że świat składa się nie tylko z tego, co możemy dotknąć, zmierzyć, zbadać czy rozłożyć na elementy pierwsze, lecz składa się także z tej sfery, do której rozum ludzki dzięki wierze ma dociekać. Tak więc „tajemnica wody jest obecna w święcie Wielkanocy, jest w nie włączona, a jednocześnie wyniesiona $\mathrm{w}$ wyższy wymiar [...]. Wielkanoc chce nam powiedzieć, że z otwartego boku Pana wytrysnęło źródło nieskończenie cenniejsze niż kiedykolwiek wytrysnęło na ziemi (por. J 4,10; 7,37; 19,34)" ${ }^{67}$, źródło, którego początek upatrujemy w trynitarnej miłości Osób Boskich.

\section{3. „NOWA PIEŚŃN" - ALLELUJA}

Trzecim elementem, wielkim symbolem, który jest obecny w liturgii Wigilii Paschalnej, jest nowa pieśń „Alleluja”, która „stanowi trzeci element symbolicznego dramatu wielkanocnej liturgii”" ${ }^{68}$. Pieśń ta ma wyjątkowy charakter i znaczenie ${ }^{69}$. Po wielkiej ciszy, która zapanowała w kościołach, następuje uroczyste odśpiewanie „Alleluja”, które obwieszcza tryumfalne wydarzenie w historii świata. Oto Ten, który został przez swoje stworzenie przybity do drzewa, zmartwychwstaje. Kładzie kres grzechowi i przynosi nową, niegasnącą nadzieję. Tej wielkiej radości, drugiej w ciągu roku liturgicznego, kiedy jej doświadcza człowiek, nie chce trzymać

${ }^{66}$ J. Ratzinger, Teologia liturgii. Sakramentalne podstawy życia chrześcijańskiego (Opera Omnia, t. 11), s. 194.

${ }^{67}$ Tenże, Jezus z Nazaretu. Studia o chrystologii (Opera Omnia, t. 6/2), s. 779.

${ }^{68}$ Tenże, Jezus z Nazaretu. Studia o chrystologii (Opera Omnia, t. 6/2), s. 781.

${ }^{69}$ Por. Benedykt XVI, Światło zmartwychwstałego Chrystusa przenika w noce dziejów, s. 26. 
wyłącznie dla siebie, lecz chce ją obwieścić wszystkim, których spotka ${ }^{70}$, chce ją wyśpiewać. Tym wyrazem w liturgii Wigilii Paschalnej jest owa „nowa pieśn”” - „Alleluja”.

Jednak czym jest „Alleluja”? Kardynał Ratzinger ujmuje to następująco:

słowo „Alleluja” było początkowo z pewnością wyrażeniem hebrajskim, które znaczy „Chwalcie Jahwe”. W liturgii wielkanocnej znaczenie to pozostaje jednak tylko jako bardzo dalekie tło. Gdyby było najważniejsze, wtedy słowo to zostałoby przetłumaczone. Tutaj nie chodzi jednak o coś takiego, co można przekładać. Alleluja jest po prostu pozbawionym słów wyśpiewaniem radości, której niepotrzebne są już słowa, ponieważ jest ponad słowami. Upodabnia się przez to do pewnych form radosnych, triumfalnych okrzyków, występujących we wszystkich językach jako cud radości i uciechy, której oznaki są u wszystkich narodów ${ }^{71}$.

Brak słów iubilatio, jak określał to Augustyn, oznacza, że nie potrafimy ująć w słowa tego, co dzieje się w sercu, co dzieje się w duszy człowieka, co śpiewa w jego wnętrzu. To właśnie dzieje się w człowieku, kiedy przepełnia go (niczym uderzenie pioruna) wielka, niczym nieprzebrana radość, do której nie potrafi znaleźć słów. To właśnie wtedy ten śpiew wypływający $\mathrm{z}$ radości staje się iubileus, który jest wyrazem tego, że wnętrze człowieka ogłasza coś, czego żadne ludzkie słowo nie jest w stanie oddać. Takie wyśpiewanie iubileus należy się właśnie Temu, który jest Niewypowiedziany, którego wszystkie słowa świata nie zdołają opisać, nie zdołają wyrazić. Stąd pozostaje tylko człowiekowi to: radowanie się bez słów ${ }^{72}$ „i rozrywanie wszelkich granic sylab niezmierzonym wymiarem [...] radości”73.

${ }^{70}$ Por. Benedykt XVI, Światło zmartwychwstałego Chrystusa przenika w noce dziejów, s. 26.

${ }^{71}$ J. Ratzinger, Jezus z Nazaretu. Studia o chrystologii (Opera Omnia, t. 6/2), s. 780 .

${ }^{72}$ Por. J. Ratzinger, Jezus z Nazaretu. Studia o chrystologii (Opera Omnia, t. 6/2), s. 781 .

${ }^{73}$ J. Ratzinger, Jezus z Nazaretu. Studia o chrystologii (Opera Omnia, t. 6/2), s. 781 . 
Dla kard. Ratzingera „śpiew oznacza, że człowiek wychodzi poza granice czystej rozumności i wpada w pewnego rodzaju ekstazę"74. Przykładem, który to opisuje, jest przejście Izraelitów przez Morze Czerwone. To właśnie tam mamy pierwszą wzmiankę o śpiewie. Naród Wybrany wyśpiewał pieśń, kiedy był pewien, że został uwolniony z jarzma niewoli Egiptu, kiedy przebył drogę „nowego” narodzenia, drogę do nowej ziemi. Kiedy przechodził przez groźne wody, wiedział, że kończy coś się, że kończy się okres zniewolenia, a nastaje czas wolności, czas oddychania pełną piersią, czas życia ${ }^{75}$. W tym obrazie Kościół odnajduje swoje wyzwolenie, dzięki któremu może pełnym głosem swoich wiernych śpiewać „nową pieśń" dziękczynienia za ocalenia, za wydarzenie, które zmieniło życie świata. Kościół ma świadomość tego, że wyrwany siłom śmierci i zła, został porwany przez inną, nową siłę, która kieruje go ku Bogu, ku Temu, który jest Drogą, Prawdą, i Życiem (por. J 14,6). Ku Temu, który jest miłością ${ }^{76}$.

Święty Paweł w liście do Filipian pisał: „radujcie się zawsze w Panu; jeszcze raz powtarzam, radujcie się!” (Flp 4,4). Radości, o której pisał Apostoł Narodów, „nie można nakazać. Można ją tylko dać. Zmartwychwstały Pan daje nam radość - prawdziwe życie" ${ }^{77}$, mówił Benedykt XVI podczas Wigilii Paschalnej w 2010 roku. Jest to właśnie ta „pieśń radości, która nie potrzebuje słów"78. W tym śpiewie, jak podkreśla Joseph Ratzinger, trzecim elementem jest „sam człowiek, w którym tkwi owa pierwotna możność śpiewania i radości. Jest to niejako pierwsze odsłonięcie tego, czym kiedyś możemy i powinniśmy być: tego, że cała nasza istota stanie się kiedyś jedną wielką radością"79.

s. 780 .

${ }^{74}$ J. Ratzinger, Jezus z Nazaretu. Studia o chrystologii (Opera Omnia, t. 6/2),

75 Por. Benedykt XVI, Światło zmartwychwstałego Chrystusa przenika w noce dziejów, s. 26.

${ }^{76}$ Por. Benedykt XVI, Światło zmartwychwstałego Chrystusa przenika w noce dziejów, s. 27.

77 Tenże, Śmierć i zmartwychwstanie Chrystusa staly się dla nas lekarstwem na wieczność, s. 33.

${ }^{78}$ Tenże, Śmierć i zmartwychwstanie Chrystusa stały się dla nas lekarstwem na wieczność, s. 33.

${ }^{79}$ J. Ratzinger, Jezus z Nazaretu. Studia o chrystologii (Opera Omnia, t. 6/2), s. 781 . 
„Nową pieśń”, którą intonujemy po trzecim czytaniu, „śpiewamy ją jako naszą pieśń, bowiem także my, mocą Boga, zostaliśmy wydobyci z wody i wyzwoleni do prawdziwego życia”" "Świąteczna pieśń wielkanocnej liturgii pokazuje, że głos ludzki może nie tylko krzyczeć, jęczeć, żalić się, mówić, lecz również - śpiewać”1. Ta „nowa pieśń” jest pieśnią

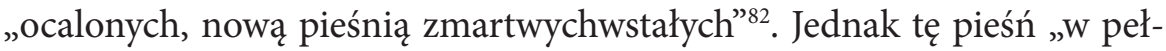
nym tego słowa znaczeniu będziemy śpiewać dopiero w «nowym świecie, kiedy Bóg nazwie nas «nowym imieniem» (Ap 2,17), kiedy wszystko stanie się nowe" 83 , a my wraz z przemienionym stworzeniem będziemy oddawać Bogu chwałę i śpiewać hymn wdzięczności z całym tryumfującym Kościołem i zastępami niebieskimi.

\section{ZAKOŃCZENIE}

Trzy wielkie symbole Wigilii Paschalnej ukazują nam rzeczywistość, której od razu człowiek nie jest w stanie ogarnąć. Pomaga nam tu bogate nauczanie Josepha Ratzingera - Benedykta XVI, które w perspektywie wiary daje czytelnikowi głębsze rozumienie wyżej omawianych symboli. Daje nam rozpoznać w nich Tego, dzięki Któremu dokonało się odkupienie dzieła stworzenia. Światło wskazuje nam Jezusa Chrystusa jako Tego, Który prowadzi przez ciemny świat do miejsca, będącego niegasnącą krainą wiecznego Słońca oraz Tego, Który oświeca człowieka. Woda ukazuje Chrystusa jako Tego, Który obmywa, odradza i „nawadnia” człowieka. Natomiast „nowa pieśń” jest hymnem duszy i ciała wznoszonym do Boga za dar, który zdziałał w człowieku i dla człowieka, a Którego ludzkość nie jest w stanie wyrazić słowami.

${ }^{80}$ Benedykt XVI, Światło zmartwychwstałego Chrystusa przenika $w$ noce dziejów, s. 27.

${ }^{81}$ J. Ratzinger, Tajemnica Jezusa Chrystusa, s. 112.

${ }^{82}$ Benedykt XVI, Światło zmartwychwstałego Chrystusa przenika $w$ noce dziejów, s. 27.

${ }^{83}$ J. Ratzinger, Jezus $z$ Nazaretu. Studia o chrystologii (Opera Omnia, t. 6/2), s. 780 . 
Streszczenie. Artykuł omawia trzy wielkie symbole, które dominują w liturgii Wielkiej Soboty: światło, ogień, wodę i „nową pieśń" - Alleluja w oparciu na nauczaniu Josepha Ratzingera - Benedykta XVI. Te trzy wielkie symbole wpisują się i wyjaśniają nam, czym jest tajemnica Wielkanocy, tajemnica naszego życia. Światło, ogień rozprasza ciemności świata oraz oświeca człowieka, oświeca jego drogę, wskazując kierunek jego ziemskiej wędrówki. Woda jest symbolem obmycia z brudu grzechu, symbolem zanurzenia w śmierci i narodzeniem się do nowego stworzenia. „Nowa pieśń” - Alleluja jest przejawem radości, gdzie słowa nie mają większego znaczenia. Jest przejawem tego, czego dokonał Jezus Chrystus dla rodzaju ludzkiego, dla świata. Te trzy symbole Wigilii Paschalnej wpisują się w cały kontekst życia chrześcijanina: od początku aż do końca, kiedy to, co przed ludzkimi oczami, w czasie ziemskiej drogi jest zakryte, a objawi się w pełni, kiedy wejdzie do chwały Boga, kiedy to, co na ziemi ukazywane jest pod postacią symboli, tam odsłoni się $\mathrm{w}$ pełni.

Słowa kluczowe: światło; ogień; woda; „nowa pieśń” - Alleluja; Wigilia Paschalna; Joseph Ratzinger - Benedykt XVI; paschał; zmartwychwstanie.

Abstract. Three Great Baptismal Symbols of the Paschal Vigil in the Teaching of Joseph Ratzinger - Benedict XVI. The article discusses three great symbols which dominate in the liturgy of Easter Vigil, based on the teaching of Joseph Ratzinger - Benedict XVI: light, fire, water and a "new hymn" - Alleluia. These three great symbols are inscribed in and explained to the faithful the mystery of Easter, the mystery of our life. Light and fire dispel darkness of the world, enlighten man and also illuminate human way indicating the direction of our earthly pilgrimage. Water is a symbol of cleansing sins, a symbol of submerging in death and being born as a new creation. A "new hymn" - Alleluia is a sign of joy where the words do not have a big significance. It is a sign of what Jesus Christ did for the mankind and the world. These three symbols of the Paschal Vigil are inscribed in the entire context of Christian life: from the beginning until the end when all that has been hidden from human eyes in the course of our earthly pilgrimage is revealed in its fullness. When man enters the glory of God everything which has been shown in a symbolic form on earth will be fully revealed.

Key words: light; fire; water; "new hymn" - Alleluia; Paschal Vigil; Joseph Ratzinger - Benedict XVI; Paschal candle; Resurrection. 


\section{BIBLIOGRAFIA}

Benedykt XVI, Bóg zstąpił w otchłań grzechu, aby każdemu podać rękę, „L'Osservatore Romano" wyd. pol., 300 (2008) 2, s. 35-36.

Benedykt XVI, Chrzest oświeca świattem Chrystusa $i$ wprowadza w tajemnicę «Boga-z-nami», „L'Osservatore Romano” wyd. pol., 320 (2010) 2, s. 21-22.

Benedykt XVI, Nasze wielkie "tak” dla kultury życia, „L”Osservatore Romano” wyd. pol., 282 (2006) 4, s. 31-32.

Benedykt XVI, Niebo otwarte nad dziećmi, „L'Osservatore Romano” wyd. pol., 350 (2012) 2, s. $22-24$.

Benedykt XVI, Piękno chrztu świętego, „L'Oservatore Romano” wyd. pol., 282 (2006) 4, s. 46.

Benedykt XVI, Śmierć i zmartwychwstanie Chrystusa stały się dla nas lekarstwem na wieczność, „L’Osservatore Romano” wyd. pol., 323 (2010) 6, s. 31-33.

Benedykt XVI, Światło zmartwychwstałego Chrystusa przenika w noce dziejów, „L'Osservatore Romano", wyd. pol. 314 (2009) 6, s. 25-27.

Benedykt XVI, W przededniu „Triduum” paschalnego, „L'Osservatore Romano”, wyd. pol., 303 (2008) 5, s. 4-5.

Benedykt XVI, Wasze dzieci sa cennym darem Pana, który napełnia ich serca swoja miłościa, „L'Osservatore Romano” wyd. pol., 331 (2011) 3, s. 16-18.

Benedykt XVI, Wielkanoc to dzień nowego stworzenia, „L'Osservatore Romano” wyd. pol. 343 (2012) 5, s. 20-21.

Benedykt XVI, Zmartwychwstały Chrystus ogarnia cały świat, „L'Osservatore Romano” wyd. pol., 283 (2006) 5, s. 25-27.

Benedykt XVI, Zmartwychwstanie Jezusa zakończeniem dzieła stworzenia i początkiem nowego życia, „L'Osservatore Romano” wyd. pol., 334 (2011) 6, s. 41-43.

Glaeser Z., Liturgiczne „doświadczenie” misterium Boga według teologii prawosławnej, „Liturgia sacra. Liturgia - Musica - Ars”, 2 (1996) -4, s. 49-63.

Koch G., Sakramentologia - zbawienie przez sakramenty, tłum. W. Szymona, Kraków 1999 (Podręcznik teologii dogmatycznej, traktat 10, red. W. Beinert).

Nadolski B., Liturgika, t. 1: Liturgika fundamentalna, Poznań $2014^{2}$.

Nadolski, B., Leksykon symboli liturgicznych. Per visibilia ad invisibilia, Kraków 2012.

Parusel P., Symbol, tłum. Z. Wesołowski, w: H. Waldenfels (rLeksykon religii, Warszawa 1997, s. 446.

Ratzinger J. - Benedykt XVI, Moje życie. Autobiografia, wyd. poszerzone, tłum. W. Wiśniowski i K. Łapiński, Częstochowa 2013.

Ratzinger J., Jezus z Nazaretu. Studia o chrystologii (Opera Omnia, t. 6/2), red. pol. K. Góźdź i M. Górecka, tłum. W. Szymona, Lublin 2015.

Ratzinger J., Kościół - znak wśród narodów. Pisma eklezjologiczne i ekumeniczne (Opera Omnia, t. 8/2), red. pol. K. Góźdź i M. Górecka, tłum. W. Szymona, Lublin 2013. 
Ratzinger J., Lud i Dom Boży w nauce św. Augustyna o Kościele. Rozprawa doktorska oraz inne opracowania nauki Augustyna i teologii ojców Kościoła (Opera Omnia, t. 1), red. pol. K. Góźdź i M. Górecka, tłum. W. Szymona, Lublin 2014.

Ratzinger J., Rozumienie objawienia $i$ teologii historii według Bonawentury. Rozprawa habilitacyjna i studia nad Bonawentura (Opera Omnia, t. 2), red. pol. K. Góźdź i M. Górecka, tłum. J. Merecki, Lublin 2014.

Ratzinger J., Tajemnica Jezusa Chrystusa, tłum. J. Płoska, Kielce 2005².

Ratzinger J., Teologia liturgii. Sakramentalne podstawy życia chrześcijańskiego (Opera Omnia, t. 11), red. pol. K. Góźdź i M. Górecka, tłum. W. Szymona, Lublin 2012.

Ratzinger J., Wstańmy i idźmy za Chrystusem, światłem i życiem, „L'Osservatore Romano” wyd. pol., 274 (2005) - 60. 